\title{
PREVENTING THE OPERATION OF UNTAXED BUSINESS BY TAX-EXEMPT ORGANIZATIONS
}

Many organizations exempt from federal income tax ${ }^{1}$ raise money by engaging in business. The belief that such businesses, if not taxed, would unfairly compete with taxed concerns caused Congress in 1950 to * place a tax on the "unrelated" business income ${ }^{2}$ of certain exempt organizations. ${ }^{3}$ Before 1950 some courts had sought to resolve the same problem by removing exemption from the entire organization. At the Revenue

1 INT. REv. CoDE of 1954, §501(c), provides tax exemption for seventeen types of organizations. Best known are: religious, scientific, and educational organizations, $\S 501(c)(3)$; social welfare organizations, $\S 501(c)(4)$; business leagues, real estate boards, and chambers of commerce, § 501(c)(6); and social clubs, §501(c)(7). Exemption is also provided for certain employee pension trusts, $\$ 501$ (a).

2 INT. REv. CODE OF 1954, $\S \S 511-14$. For a general description of the provisions see Comment, Colleges, Charities and the Revenue Act of 1950, 60 YALE L.J. 851 (1951). The unrelated business income tax provisions divide the exempt and business functions of certain organizations as did nineteenth century courts applying state property taxes. See, e.g., Methodist Episcopal Church v. Chicago, 26 Ill. 482 (1861); Proprietors of South Congregational Meeting House v. Lowell, 42 Mass. (I Met.) 538 (1840) (Shaw, J.). In the first taxable year to which $\$ \$ 511-14$ applied, $\$ 37.00$ of unrelated business income tax was collected. The amount has never exceeded $\$ 2,000,000$. Letter from Mitchell Rogovin, Chief Counsel, Internal Revenue Service, to the University of Chicago Law Review, Feb. 25, 1965, on file at the University of Chicago Law Review. The provisions do not apply to all tax-exempt organizations, but only to organizations exempt by $\$ \$ 401,501(c)(2), 501(c)(3), 501(c)(5), 501(c)(6)$, and 501(c)(17). In addition to the unrelated business income tax, a tax was placed on "feeder" corporations which operated businesses and turned over all their income to exempt organizations. INT. REV. CODE of $1954, \S 502$.

3 Other limitations were placed on these organizations at the same time. To prevent accumulation of funds to finance or control the business operations of donors or founders of exempt trusts and foundations a provision was added to the Code which removes exemption for "unreasonably" accumulating income. INT. REv. CODE OF 1954, $\S 504(\mathrm{a})(\mathrm{l})$. See Riecker, Foundations and the Patman Committee Report, 63 Mick. L. REv. 95, 125-31 (1964). Provisions were also added prohibiting certain loans or payments to contributors and founders of the organization, and to corporations controlled by such persons. INT. Rev. Cone of 1954, § 503(c); see Comment, Colleges, Charities and the Revenue Act of 1950, 60 YALE L.J. 851, $868 \mathrm{n} .76$ (1951). Violation of the provisions requires removal of exemption. These provisions have been criticized as not preventing many abuses. Id. at 868, 877; Hearings Before the House Committee on Ways and Means on Revenue Revision of 1950, 81st Cong., 2d Sess. 780 (1950). To inhibit shrinkage of the tax base through purchase of income-producing real property by exempt organizations, a tax was placed on rent from certain property acquired with borrowed funds. INT. REv. CoDE of 1954, § 514. See Cary, Corporate Financing Through the Sale and Lease-Back of Property: Business, Tax, and Policy Considerations, 62 HArv. L. REv. 1 (1948); Comment, Taxation of Sale and Lease-Back Transactions, 60 YALE L.J. 879 (1951). 
Service's urging ${ }^{4}$ many have continued to use this all-or-nothing approach which denies to the socially valuable activities of the organization the benefits of tax-free investment income and of gifts which are deductible by their donors. ${ }^{5}$ This comment argues that the Congressional solution should not continue to be ignored.

I.

The two statutory provisions most often relied on by courts dealing with exempt organizations require that (1) an organization be operated "exclusively" for purposes which justify exemption, and (2) none of the organization's income "inure ... to the benefit of any private shareholder or individual." 6 Violation of either condition has caused removal of exemption. However, many of the cases both before and after 1950 which rely on these requirements can be consistently explained only as removing exemption to eliminate the evil aimed at by the unrelated business income tax provisions-the operation of competitive business.

\section{A. The Operated "Exclusively" Requirement}

The operated "exclusively" requirement has been the Commissioner's main weapon against religious, charitable, educational and social welfare organizations.7 Both it and the "no-benefit" clause were added to the Corporate Excise Tax of $1909^{8}$ in an attempt to state that an exempt

4 No case has been found in which the Commissioner urged use of the unrelated business income tax as a substitute for removal of exemption. See cases cited note 16 infra.

5 See INT. REV. CODE of 1954, § 170 (c), allowing deductions for gifts to certain organizations which meet requirements for exemption under $\$ 501$ (c).

6 INT. REv. CODE of 1954, §50I(c). The first requirement applies to organizations exempt under $\S 501(c)(3)$ (religious, charitable, scientific and educational organizations), (c)(4) (civic leagues, social welfare organizations), (c)(7) (social clubs), (c)(13) (certain cemetery companies). The second requirement applies to organizations exempt under § 501(c)(3), (c)(6) (business leagues, real estate boards, chambers of commerce), (c)(7), (c)(9) (employee beneficiary associations), (c)(10) (employee beneficiary associations), (c)(11) (teachers' retirement funds), (c)(13). Many of the organizations which must be "operated exclusively" for exempt purposes must also be "organized exclusively" for exempt purposes. But "the word 'organized' cannot be divorced from 'operated' for the true character of an organization must be drawn from the manner in which it has been operated." 6 MERTENS, INCOME TAXATION $\$ 34.07$ (Zimet rev. 1957, Supp. 1964) (citing authority). See Commissioner v. John Danz Charitable Trust, 284 F.2d 726, 734 (9th Cir. 1960) (broad powers of trustee consistent with "organized" for exempt purpose).

7 Common problems arise in applying the provisions, and cases involving different organizations freely cross-cite each other. See People's Educ. Camp Soc'y, Inc. v. Commissioner, 331 F.2d 923 (2d Cir. 1964), affirming 39 T.C. 756 (1963), cert. denied, 379 U.S. 839 (1964); Evanston-North Shore Bd. of Realtors v. United States, 320 F.2d 375. (Ct. Cl. 1963).

8 Tariff of 1909, ch. $6, \S 38,36$ Stat. 112. 
organization could operate a business without losing its exemption if its business income was used exclusively for exempt purposes. ${ }^{9}$ Thus the historically correct view before 1950 was that business profits could not be taxed if used to finance exempt activity. ${ }^{10}$ That is the rule which Congress overruled by passing the unrelated business income tax provisions. ${ }^{11}$

But instead of reading the operated "exclusively" clause as limiting the purposes for which business income may be used, courts before and after 1950 have read it as limiting the amount of business activity permissible. "Exclusively" has been read "primarily" which in turn has been given two meanings, both of which rest on competition with taxed businesses.

The first requires that business operations be not "disproportionate" to exempt activity. The Treasury Regulations adopt this reading, requiring analysis of the "size and extent of the trade or business and the size and extent of activities which are in furtherance of exempt purposes."12 In Aviation Club v. Commissioner ${ }^{13}$ the Tenth Circuit accepted this view, removing exemption from a social club when its wartime sale of liquor and food to the general public exceeded prewar sales to its members by about twenty times. The selling was found to be "wholly disproportionate"14 to the exempt activity. But untaxed sale of liquor and food was allowed an identical organization by the Tax Court in Aviation Country

( The present exemption statute originated in the Corporate Excise Tax of 1909 which imposed a tax on "every corporation, joint stock company or association, organized for profit and having a capital stock represented by shares ..." Tariff 1909, ch. 6, § 38, 36 Stat. 112. Although the bill's language implicitly excluded non-profit and non-stock companies from taxation, Senator Bacon of Georgia feared that the language did not make clear that a charitable corporation could engage in a profitmaking business and remain exempt. 44 CoNG. REc. 4151 (1909). Consequently he introduced the operated "exclusively" and "no-benefit" clauses to the definition of taxexempt organizations to emphasize that as long as the business income was used to support a charitable activity exemption would not be lost. The Senator was concerned that a church-operated publishing house not lose its exemption. Ibid. The organization had previously had its exemption from state property taxes challenged and sustained. See Book Agents of Methodist Episcopal Church v. Hinton, 92 Tenn. 188, 21 S.W. 321 (1893).

10 The leading case is Roche's Beach, Inc. v. Commissioner, $96 \mathrm{F.2d} 776$ (2d Cir. 1938). See 6 MERTENS, op. cit. supra note 6 , at $\S 34.07 \mathrm{nn} .79-83$.

11 See People's Educ. Camp Soc'y, Inc. v. Commissioner, 331 F.2d 932, 935 (2d Cir. 1964), affirming 39 T.C. 756 (1963), cert. denied, 379 U.S. 839 (1964).

12 Treas. Reg. § 1.501(c)(3)-1(e)(1) (1959), as amended T.D. 6525, 1961-1 CuM. BuLl. 186. One Revenue Service official has noted that these are "vague criteria" and that such "physical comparisons are not very meaningful." Statement by Mitchell Rogovin, then Assistant to the Commissioner of Internal Revenue, at 17th Annual Federal Tax Conference, The University of Chicago Law School, October 29, 1964.

13162 F.2d 984 (10th Cir. 1947).

$14 I d$. at 986. 
Club, Inc. ${ }^{15}$ when the business remained at the size necessary to serve members only. Each club provided similar services to its members, but because the first ran a larger competitive business it lost its exemption.

The second and more frequent judicial reading allows operation of "incidental" but not "substantial" businesses. ${ }^{16}$ Scripture Press Foundation $v$. United States ${ }^{17}$ illustrates the difficulty of using this test and suggests that prevention of competitive business activity best explains removal of exemption. To improve the quality of Sunday school teaching materials the foundation published and sold religious literature, trained teachers and engaged in door-to-door evangelism. The question for decision was described in language typical of the operated "exclusively" cases:

was the sale of religious literature by the plaintiff in this case incidental to the plaintiff's religious purposes? Or were plaintiff's religious objectives incidental to the sale of religious literature? ${ }^{18}$

In denying exemption the Court of Claims emphasized the disparity between expenditures for religious-educational programs and the accumulated capital surplus from the publishing activity. Without explaining, it rejected the contention that the publishing business was exempt educational activity.19 The court's emphasis on the competitive character of the activity may explain the otherwise unarticulated justification for removal of exemption.

[T]he sale of these materials, however religiously inspired, involved the plaintiff directly in the conduct of a trade or business for profit ....

It should be remembered that there are many commercial concerns which sell Bibles, scrolls, and other religious and semi-

1521 T.C. 807 (1954).

16 See Better Business Bureau v. United States, 326 U.S. 279 (1945) (construing § 811(b)(8) of the Social Security Act, 49 Stat. 620, 639 (1935), 42 U.S.C. § 1011(b) (1947), drawn almost verbatim from the predecessor of INT. REv. CODE OF 1954, § 50I(c)(3)); Universal Oil Prods. Co. v. Campbell, 181 F.2d 451, 464-65 (7th Cir. 1950); American Institute for Economic Research v. United States, 157 Ct. Cl. 548, 554, 302 F.2d 934, 938 (1962); Golden Rule Church Ass'n, 41 T.C. 719, 728 n.8 (1964); People's Educ. Camp Soc'y, Inc., 39 T.G. 756, 772 (1963), aff'd, 331 F.2d 923 (2d Cir. 1964); Donald G. Griswold, 39 T.C. 620, 634 n.7 (1962); Stevens Bros. Foundation, Inc., 39 T.C. 93, 109 n.10 (1962); Best Lock Corp., 31 T.C. 1217, 1236 (1959) (15\% is "substantial"); Estate of Thayer, 24 T.C. 384, 392 (1955) (2\% insubstantial); Sugarman \& Pomeroy, Business Income of Exempt Organizations, 46 VA. L. REv. 424, 425 (1960).

17152 Ct. Cl. 463, 285 F.2d 800 (1961), cert. denied, 368 U.S. 985 (1962).

18 Id. at $469,285 \mathrm{~F} .2 \mathrm{~d}$ at 804 .

19 Id. at $472-73,285 \mathrm{~F} .2 \mathrm{~d}$ at 806. 
religious literature which have not been granted exemption as to that part of their business. 20

A number of other cases suggest the same underlying rationale. In Trinidad v. Sagrada Orden, ${ }^{21}$ the Supreme Court held the sale of wine and candy by a religious order to be "incidental," emphasizing that the small sales "do not amount to engaging in trade . . . It is not claimed that there is any selling to the public or in competition with others." 22 Other cases have held, without discussion, that organizations were operated "exclusively" for exempt purposes when they received income from the occasional sale ${ }^{23}$ or lease ${ }^{24}$ of land or from the sale of interests in publishing rights 25 -activities which were not regarded as engaging in business. ${ }^{26}$ Yet exemption has been removed when organizations received half the profits of a construction job, ${ }^{27}$ or engaged in very active stock trading. ${ }^{28}$

The recent case of People's Educ. Camp Soc'y, Inc. v. Commissioner ${ }^{20}$

20 Id. at 472 \& n.11, 285 F.2d at 806 \& n.l1. Scripture Press Foundation cited, but did not distinguish, Saint Germain Foundation, 26 T.C. 648 (1956), which sustained the exemption of a,church which sold literature describing its beliefs. The case may be distinguished by the fact that no other enterprise provided literature on the faith, and consequently the church was not in competition with commercial publishers. Golden Rule Church Ass'n, 41 T.C. 719 (1964), allowing businesses to be operated by a church association, may also be distinguished on the grounds that the business had no competitive advantage. In Golden Rule the businesses were operated at a loss by "student ministers" as a part of their religious way of life and avoided undercutting similar commercial enterprises. 41 T.C. at 725,729 . The court apparently sustained exemption on the first amendment, stating that "we have grave doubts that a contrary conclusion would be permitted under the Constitution of the United States." Id. at 729.

21268 U.S. 578 (1923).

22 Id. at 582.

23 Jack Little Foundation v. Jones, 102 F. Supp. 326 (W.D. Okla. 1951); Town and Country Club, I CGH Tax Ct. Mem. 334 (1942).

24 Akron Clinic Foundation v. United States, 226 F. Supp. 515 (N.D. Ohio 1964).

25 Bob and Dolores Hope Foundation, 61 U.S. Tax Cas. 80236 (S.D. Cal. 1961).

26 See Surrey \& Warren, Federal Income Taxation 689-90 (1962); Surrey \& Warren, Federal Income Taxation (Supp. 1964, at 123); cf. Commissioner v. Ferrer, 304 F.2d 125 (2d Cir. 1962).

27 Stevens Bros. Foundation, Inc. v. Commissioner, 324 F.2d 633 (8th Cir. 1963), reversing in part 39 T.C. 93 (1963).

28 Randall Foundation v. Riddell, 244 F.2d 803 (9th Cir. 1957). Although active trading of securities on a stock exchange is treated as producing capital gains rather than ordinary income, it has been suggested that the activity can be regarded as being so active as to qualify as the business of trading. See Surrey \& WARren, Federal INCOME TAXATION 698-99 (1962). The court in Randall Foundation regarded the foundation's stock trading activities as engaging in business on the ground that: "it is conceivable that a business corporation might well have been organized to do exactly what Foundation did." 244 F.2d at 807.

29331 F.2d 923 (2d Cir. 1964), affirming 39 T.C. 756 (1963), cert. denied, 379 U.S. 839 (1964). 
explicitly rested removal of exemption on the prevention of competitive advantage. The Camp Society supported one of the largest libraries on the labor movement, Socialism and Communism by operating a luxury resort in the Pocono Mountains. The Court of Appeals for the Second Circuit emphasized the competitive character of the resort.

$[\mathrm{P}]$ etitioner's Poconos resort operation is anything but small, and it competes actively for the public's business with other commercial resorts in the Poconos area. More importantly, unlike the corporation in the Sagrada Orden case, petitioner has, over the years, applied substantial portions of its income to expanding its business operations . . . . .

These cases, in reading operated "exclusively" to require removal of exemption if the business is more than "incidental," are inconsistent with the unrelated business income tax provisions, which clearly envisage the operation of a business. The inconsistency cannot be resolved by construing the provisions as applicable only to "insubstantial" or "incidental" income. The Code expressly excluded $\$ 1,000$ from unrelated business taxable income, ${ }^{31}$ a Committee Report explains, because such "incidental" amounts are too inconvenient to collect. ${ }^{32}$ The courts' view means that every exempt organization which engages in activity that could be considered a business operates at the risk of losing its exemption. Even a sincere belief that the sale of religious books was a religious activity did not prevent the Scripture Press Foundation, for example, from losing the benefits of exemption for all its activities.

\section{B. The "No-Benefit" Requirement}

The "no-benefit" 33 requirement, with the operated "exclusively" clause, was inserted in the Corporate Excise Tax of 1909 as part of the at-

30 Id. at 934. The court refused to apply the destination of income test to the organization's business income, in view of the policy of the unrelated business income tax provisions-prevention of unfair competition. Id. at 935. It could not, however, prevent the competition by applying the provisions directly because they are inapplicable to social welfare organizations of the type involved in the case. See note 2 supra.

31 INT. REv. CODE OF 1954, \& 512(b)(12).

32 H.R. REp. No. 2319, 81 st Cong., 2d Sess. 36-37 (1950), 1950-2 CuM. Buld. 380, 409.

33 The requirement that an organization not be "organized for profit" in $\S 501(c)(4)$ serves an analogous function to the "no-benefit" requirement of $\$ 501(c)$ (3). Profit to individuals is often said to violate both requirements. See Note, 50 VA. L. REv. 1243, $1245 \& \mathrm{n} .14$ (1964). But it is always possible to find some "profit" just as it is always possible to find some "benefit." Cases removing exemption from § 501(c)(4) organizations because of "profit" often may be best explained as based on the absence of any "social welfare" activity justifying exemption. See, e.g., Commissioner v. Lake Forest, Inc., 305 F.2d 814, 819 (4th Cir. 1962), reversing 36 T.C. 510 (1961) (corporation to make housing available to public not exempt when "no State or local authority and 
tempt to allow tax-exempt organizations to operate businesses as long as none of the profits were used for private objectives. ${ }^{34}$ The "no-benefit" requirement has been properly applied to remove exemptions from educational organizations which turned their net earnings over to officers or other employees of the organization, 35 from allegedly charitable organizations whose sole activity was supporting the founder's employees, ${ }^{\mathbf{6}}$ and from foundations which loaned funds to businesses in which their founder was interested. ${ }^{37}$ But the requirement has been used primarily

no civic or community entity has proclaimed ... need for, adopted or subsidized the activity sought to be exempted"); Scofield v. Rio Farms, 205 F.2d 68 (5th Cir. 1958), affirming 103 F. Supp. 515 (W.D. Tex. 1952) (cooperative farm to assist low income farmers supported by Texas law and Federal Farm Security Administration held exempt); Consumer-Farmer Milk Co-op. v. Commissioner, 186 F.2d 68 (2d Cir. 1950), affirming 13 T.C. 150 (1949) (organization not exempt which eliminated middleman in milk business); United States v. Pickwick Elec. Membership Corp., 158 F.2d 272 (6th Cir. 1946) (ruxal electric cooperative supported by Tennessee law exempt); Garden Homes v. Commissioner, 64 F.2d 593 (7th Cir. 1933) (construction of low cost housing for workers supported by Wisconsin law and the City of Milwaukee held exempt); Oregon Physicians' Serv. v. Horn, 220 Ore. 487, 349 P.2d 831 (1960) (contract medical care organization not exempt under Oregon law identical to $\$ 501(c)(4)$ ). Contra, Industrial Addition Ass'n v. Commissioner, 149 F.2d 294 (6th Cir. 1945), affirming I T.C. 378 (1942); Amalgamated Housing Corp. v. Commissioner, 37 B.T.A. 817 (1938), aff'd mem., 108 F.2d 1010 (2d Cir. 1940).

34 See note 9 supra.

35 Birmingham Business College, Inc. v. Commissioner, 276 F.2d 476 (5th Cir. 1960); Texas Trade School v. Commissioner, 272 F.2d 169 (5th Cir. 1959), affirming, 30 T.C. 642 (1958); Mabee Petroleum Corp. v. United States, 203 F.2d 872 (5th Cir. 1953); Gemological Institute of America v. Riddell, 149 F. Supp. 128 (S.D. Cal. 1957); Lorain Avenue Clinic, 31 T.C. 141 (1958).

36 Horace Heidt Foundation v. United States, 145 Ct. Cl. 322, 170 F. Supp. 634 (1959).

37 Stevens Bros. Foundation, Inc., 39 T.C. 93 (1962) (dictum); Best Lock Corp., 31 T.C. 1217 (1959); cf. Donald G. Griswold, 39 T.C. 620 (1962) (permissible loans). Although the question is not discussed, the cases suggest that exemption could be removed for making loans which violate the "no-benefit" requirement, although they do not constitute prohibited transactions under $\$ 503$ (c). The "no-benefit" requirement has also twice been used to remove the exemptions of organizations engaging in debtfinanced purchases of businesses. In one case, Emanuel N. Kolkey, 27 T.C. 37 (1956), aff'd, 254 F.2d 51 (7th Cir. 1958), exemption was removed because the sale was a "sham" and the exempt organization was used only as a perpetual conduit to pass untaxed business income back to the so-called sellers of the business. Such activity was within the proper meaning of impermissible benefit; money paid to the exempt organization was used for private purposes. In Leon A. Beeghly Fund, 35 T.C. 490 (1960), exemption was also removed on the "no-benefit" reasoning when stockholders of the vendor company were said to benefit from the opportunity quickly to liquidate their investment in the company at capital gains rates. $I d$. at 520 . But such benefit does not distinguish the case from those which have allowed exemption. See Commissioner v. Johnson, 267 F.2d 382 (Ist Cir. 1959); A. Shiffman, 32 T.C. 1073 (1959); Ohio Furnace Co., 25 T.C. 179, 193-95 (1955) (dissenting opinion). The Beeghly court's emphasis on the risk to the exempt vendee of not benefiting from the purchase better explains the result. See 35 T.C. at 520 . But no reason is apparent, or was given by the Tax Court, for removing exemption from organizations which take risks. There was 
to remove the exemption of membership organizations such as business leagues and social clubs and again can best be understood as preventing operation of competitive businesses. The "no-benefit" reasoning is easily applied to such organizations because people usually join with the expectation of some personal benefit. ${ }^{38}$ When a business is operated, by a membership organization, members inevitably benefit through reduced dues or services provided to them at low cost. Although loss of exemption has been explained by such benefits, ${ }^{39}$ the cases cannot be squared with other cases tolerating indistinguishable benefits. ${ }^{40}$

When business leagues have engaged in businesses ${ }^{41}$ which are usually carried on by profit-making organizations and the businesses are more than "incidental," exemption has been removed. General Contractors' $A s s^{\prime} n$ v. United States ${ }^{22}$ is typical. A contractors' association engaged in activities promoting the welfare of the construction industry, including

no suggestion that the organization violated the statutory prohibition against investing income in a manner jeopardizing the carrying out of exempt purposes. INT. REv. CODE OF 1954, § 504(a)(3). Beeghly is inconsistent with the other cases cited above, and cannot be justified. For the Commissioner's present approach to debt-financed sale and lease-backs see Young, Donor Foundation Dealings, N.Y.U. 22D INST. ON FED. TAX 965, 996-1002 (Sellin ed. 1964).

38 See National Leather \& Shoe Finders Ass'n, 9 T.C. 121, 126 (194'); Note, The Taxation of Business Leagues, 40 VA. L. Rev. 467,478 (1954).

39 West Side Tennis Club v. Commissioner, III F.2d 6 (2d Cir. 1940), affirming 39 B.T.A. 149 (1939), cert. denied, 311 U.S. 674 (1940) (benefit from reduction in dues); Northwest Jobbers' Credit Bureau v. Commissioner, 37 F.2d 880 (8th Cir. 1930) (benefit from service provided at cost) (alternative holding); Uniform Printing \& Supply Co. v. Commissioner, 33 F.2d 445 (7th Cir. 1929) (earnings reinvested, benefit from increased value of enterprise); Spokane Motorcycle Club v. United States, 222 F. Supp. 151 (E.D. Wash. 1963) (goods and services provided to members from business profits); Durham Merchant's Ass'n v. United States, 34 F. Supp. 71 (M.D.N.C. 1940) (benefit from services provided at cost); National Auto. Dealers Ass'n, 2 CCH Tax Ct. Mem. 291 (1943) (benefit from reduction in dues). See Note, supra note 38, at 474-79.

40 Commissioner v. Chicago Graphic Arts Fed'n, 128 F.2d 424 (7th Cir. 1942) (services which members receive at cost); Fort Worth Club v. United States, $218 \mathrm{~F}$. Supp. 431 (N.D. Tex. 1963) (rental income made increase in dues unnecessary); Huron Clinic v. United States, 212 F. Supp. 847 (D.S.D. 1962) (lease income equal to percentage of clinic's profits); Milwaukee Ass'n of Commerce v. United States, 72 F. Supp. 310 (E.D. Wis. 1947) (services provided at cost); American Refactories Institute, 6 CCH Tax Ct. Mem. 1302 (1947) (reduction in dues); Town and Country Club, 1 CCH Tax C. Mem. 334 (1942) (reduction in dues); King County Ins. Ass'n, 37 B.T.A. 288 (1938) (reduction in dues). See Note, supra note 38.

41 Business leagues originally were not allowed to engage in any business activity. See Underwriters' Lab. v. Commissioner, 135 F.2d 371, 374 (7th Cir. 1943). But the courts have based their analysis on the proposition that business activity only "incidental" to other purposes will be allowed. See notes 39-40 supra. Also, the fact that Congress placed a tax on the unrelated business income of business leagues, $\S 511$ (a)(2), supports the proposition that business leagues are allowed to engage in some business activity.

42202 F.2d 633 (7th Gir. 1953). 
the conduct of safety schools, negotiation of collective bargaining agreements and labor disputes, promotion of apprenticeship programs, and preparation of building codes and bidding procedures. For a fee it also conducted engineering surveys of construction jobs being considered by members. The surveying service was "identical in scope and purpose with one prepared by a private survey organization." 43 Exemption was removed allegedly because the surveys constituted benefit to members. In rejecting the contention that the surveys were only incidental activity, the Court of Appeals for the Seventh Circuit noted that they accounted for approximately forty per cent of the organization's expenses.44 But exemption has been sustained in other cases in which equal or greater percentages of income or expense resulted from profit-making activity. Thus, a printers' association which received over forty per cent of its income from business, and a trade association which received practically all of its income from the operation of trade shows have been held exempt. 45

It has been suggested that exemption will only be lost if benefits are provided for individual members of the organizations, as in General Contractors' Ass'n, rather than to members as a group. The Court of Claims recently took this position in Evanston-North Shore Bd. of Realtors $v$. United States, ${ }^{46}$ in denying exemption to a real estate board which provided a listing service for brokers buying or selling property. The court concluded that "when each member contributes in proportion to what he receives [in listing services], it is a strong indication that the benefits are not ... 'inherently group benefits' ..."47 warranting exemption. But the conclusion that services are sold to individual members amounts to no more than recognition that the organization is engaging in the business of selling the services. Since the profits from the listing service varied from twenty-seven to forty per cent of the organization's total income, Evanston-North Shore Bd. of Realtors cannot be squared with cases allowing business income to be forty per cent or more of the organization's total receipts. 48

Characterization of the profit-making as non-competitive in cases sustaining exemption may distinguish the results. In American Institute of

43 Id. at 636.

44 Id. at 638.

45 Commissioner v. Chicago Graphic Arts Fed'n, 128 F.2d 424 (7th Cir. 1942); American Institute of Interior Designers v. United States, 208 F. Supp. 201 (N.D. Cal. 1962). See Evanston-North Shore Bd. of Realtors v. United States, 320 F.2d 375 (Ct. Cl. 1963).

48320 F.2d 375 (Ct. Cl. 1963).

47 Id. at 379.

48 See cases cited note 45 supra. 
Interior Designers $v$. United States, ${ }^{40}$ for example, operation of a trade show by a business league was held by a district court to result in only "incidental" benefit to members-and the exemption was sustainedalthough the shows accounted for practically all of the organization's income and seventy per cent of its disbursements. Conduct of trade shows was not referred to as a business or as competitive..$^{50}$ On the other hand, the Tax Court removed exemption in American Auto. Ass' $n,{ }^{51}$ when the publishing, travel and insurance businesses carried on by the organization were characterized as "competitive commercial activity."'52 Although not all the cases can be explained by this rationale, courts have generally removed exemption from business leagues engaging in competitive businesses which were more than "incidental."

Preventing exempt organizations from operating untaxed businesses also best explains "no-benefit" cases which have removed exemption from social clubs for operating public sports events, but not for selling or renting land. In West Side Tennis Club $v$. Commissioner, ${ }^{53}$ exemption was removed from a club which operated a public tennis tournament in addition to its non-profit club activities. In Jockey Club v. Helvering,54 the same result was reached when a club operated a public race track. Members were said to benefit from each profit-making activity. In both cases the Court of Appeals for the Second Circuit emphasized that exemption would not have been removed if income had not been derived from the public.55 By contrast, in Scofield v. Corpus Christi Golf \& Country Club, ${ }^{56}$ the club received oil lease income from its property. Benefit to the members was held not to require removal of exemp-

49208 F. Supp. 201 (N.D. Cal. 1962).

50 No tax case has been found treating a trade show as a business. Two revenue rulings on the subject indicate only that operation of trade shows does not constitute exempt activity when sales of goods occur at the shows. Rev. Rul. 58-224, 1958-1 CuM. Bull. 242; Rev. Rul. 57-25, 1957-1 Cum. Bull. 196. Sales were not allowed at the trade shows involved in American Institute of Interior Designers, supra note 49. Cf. Texas Mobile Home Ass'n v. Commissioner, 324 F.2d 691 (5th Cir. 1963).

5119 T.C. 1146 (1953).

52 Id. at 1160. Accord, Northwest Jobbers' Credit Bureau v. Commissioner, 37 F.2d 880 (8th Cir. 1930) (not exempt, engaging in business of sort normally carried on for profit); Durham Merchant's Ass'n v. United States, 34 F. Supp. 71 (M.D.N.C. 1940) (not exempt, providing services members would otherwise have to buy); Crooks v. Kansas City Hay Dealers' Ass'n, 37 F.2d 83 (8th Cir. 1929) (exempt, not in competition with any business); National Leather \& Shoe Finders Ass'n, 9 T.C. 121 (1947) (exempt, "not competitive in any ordinary sense").

53111 F.2d 6 (2d Cir. 1940), affirming 39 B.T.A. 149 (1939), cert. denied, 311 U.S. 674 (1940).

5476 F.2d 597 (2d Gir. 1935), affirming 30 B.T.A. 670 (1934).

5576 F.2d at 598; 111 F.2d at 8 .

56127 F.2d 452 (5th Cir. 1942). 
tion and the Court of Appeals for the Fifth Circuit distinguished West Side Tennis Club and Jockey Club on the grounds that oil lease income was not derived from dealing with the public. Likewise, exemption has been sustained when clubs sold land ${ }^{57}$ or rented part of their property. ${ }^{58}$

\section{II.}

This comment has argued that many courts using the operated "exclusively" and "no-benefit" requirements to remove exemption are responding to the same evil at which the unrelated business income tax provisions are aimed-operation of an untaxed business. It is worth noting, however, that untaxed businesses may not have the undesirable effects assumed by Congress and the courts. Congress was told that the competitive advantage lay in their ability to cut prices and accumulate surpluses for expansion. ${ }^{59}$ Yet under competitive conditions all firms in an industry produce until the cost of another unit of output equals the additional revenue it will bring. ${ }^{60}$ Because an income tax is levied only on profits, it will not be relevant in determining when that equalization point is reached. Consequently, except when economic "costs" are not deductible as business "expenses"-as when they do not meet the statutory requirement that they be "ordinary and necessary"61-an income

57 Koon Kreek Klub v. Thomas, 108 F.2d 616 (5th Cir. 1939); Santee Club v. White, 87 F.2d 5 (1st Cir. 1936).

58 Town and Country Club, 1 CCH Tax Ct. Mem. 334 (1940). Cf. Jack Little Foundation v. Jones, 102 F. Supp. 326 (W.D. Okla. 1951). Such selling or leasing would go untaxed even under the unrelated business income tax provisions. See § 512(b).

59 Hearings Before the House Committee on Ways and Means on Revenue Revision of 1950, 81st Cong., 2d Sess. 590 (1950) [hereinafter cited 1950 Hearings] (statement for American Hotel Association). Congressman Dingell stated in referring to a macaroni company owned by New York University: "From the purely competitive standpoint .... the advantage of a tax-exempt corporation . . . is so great that, if something is not done to level it off, the macaroni monopoly will be in the hands of the universities .... Eventually all the noodles in this country will be produced by corporations held or created by universities . . . and there will be no revenue to the Federal Treasury from this industry." 1950 Hearings 579-80. The assumption of competitive advantage to exempt organizations was disputed only once. See Hearings Before the House Committee on Ways and Means on Proposed Revision of the Internal Revenue Code, 80th Cong., Ist Sess. 3527 (1948) (statement for New York University). Even the representatives of exempt organizations accepted the competitive advantage assumption. See 1950 Hearings 495 (statement by the Treasurer of Harvard University), 503 (statement by the President of the Massachusetts Institute of Technology for the Association of American Universities).

60 See, e.g., Due, Government Finance, An Economic Analysis 223 (1959); Krzyzanlak \& Musgrave, The Shifting of the Corporation Income Tax 2 (1963).

61 INT. REV. CODE of 1954, § 162. Cost of production for a taxpaying firm will include the tax on the amount of the deduction which is not allowed. Since this "tax cost" is not borne by an untaxed firm its economic costs will be less than those of its taxed competitor, its equalization point will differ, and if the firm is a large part of the industry price will drop. 
tax will not affect the price charged or the volume of production.62 Again, the ability to accumulate funds faster would give the exempt organization no advantage because if there is opportunity for profitable expansion taxed businesses will be able to obtain funds in money and capital markets. ${ }^{63}$

Although Congress' solution rests on doubtful economic assumptions, it can be justified as preventing tax base shrinkage, and unlike the courts' solution, it avoids needlessly handicapping exempt activities. Consequently, whenever an organization engages in some activity warranting exemption, whether it is a charity or a business league, it should be taxed only on its unrelated business income.

It may be objected that in reporting the unrelated business income tax provisions the Senate Committee on Finance stated they were not meant to change existing rules for determining exempt status. ${ }^{64}$ But as the court recognized in People's Educ. Camp Soc'y, the provisions would be largely surplus if they could not be applied to the very problem for which they were intended. ${ }^{65}$

Further, Congress should make the provisions applicable to organizations not now covered which may engage in business. ${ }^{66}$ The provisions

62 Economists regard the businessman's return on his investment as a "cost"; the tax collector calls it "profit." But the fact that this cost is taxed will not make the taxed firm's price-output combination differ from that of its untaxed competitors. For both kinds of firms, the return demanded will equal that available from alternative investments and is thus an "opportunity cost." Since an untaxed firm can presumably get an equal untaxed return from some alternative investment, its opportunity cost will exceed that of the taxed firm's by exactly the amount the latter is taxed and there will be no difference in the total costs of the taxed and untaxed firms.

63 Funds will not be available any more cheaply to the businesses of an exempt organization, for even if the organization is able to accumulate funds without loss of exemption, see note 3 supra, the organization foregoes profitable uses of the money being accumulated. This "opportunity cost" must be recognized in comparing the cost paid for money and capital by the business of an exempt organization with the price paid in the money and capital markets by taxed businesses.

64 S. REp. No. 2375, 81 st Cong., 2d Sess. 29 (1950), 1950-2 Cum. Bulr. 483, 505.

65331 F.2d at 935 .

66 The Treasury has gone to the opposite extreme, suggesting to Congress that private foundations be forbidden to own more than a twenty per cent interest in any business. Treasury Department, Treasury Department Report on Private FoundaTIONS (Comm. Print, Senate Committee on Finance 1965) 36-37 [hereinafter cited as Treasury ReporT]. The Treasury has five objections to foundation-operated businesses:

(1) The Treasury suggests that serious competitive advantage results from the ability of foundations to pay more than taxpaying purchasers for businesses purchased through sale and lease backs, see note 3 supra, and from the foundations' ability to capitalize and subsidize their businesses more easily than taxed enterprises. TREASURY REPORT 31-34. The ability to pay more raises the same problem presented to Congress in 1950 and resolved by taxing income received from certain kinds of property purchased with borrowed funds. See note 3 supra. As the Treasury indicates, a problem results from the fact that the tax is not presently applied to all income from debt-financed 
were not applicable to such groups, according to a Treasury spokesman, because the ability of those organizations to engage in business is already limited by the Code.67 But that is not true of "social welfare" organizations and "social clubs." Commentators have divided over whether, until Congress acts, those organizations should lose their exemption for engaging in business or whether the "destination" test should

property. Treasury Report 31-32. Insofar as the problem results from the limited scope of the tax, it can be eliminated by taxing all income from debt-financed property, thus removing the advantage resulting from the ability of exempt organizations to pay the purchase price more rapidly out of business profits undiminished by taxation. But it is doubtful that foundations will pay more than taxpaying purchasers for businesses which they purchase with their own funds, for all purchasers want to maximize the return on invested funds. The second sort of competitive advantage found offensive by the Treasury is said to result from the ability of foundations to accumulate funds to capitalize or subsidize their businesses. Id. at 32-34. But see text accompanying note 63 supra. Any funds merely retained by the foundation for indefinite purposes may be forced into use by provisions suggested by the Treasury, TREASURY REPORT 26-30, or, in case the funds are retained in the business, by making applicable the $\$ 531$ surtax on amounts accumulated beyond the reasonable needs of the business. The Treasury suggests that such a solution would require an "arduous, case-by-case examination" by the Revenue Service. TREASURY REPORT 34 n.21. But such examinations are carried out presently under $\$ 531$, and would have to be carried out under the Treasury's proposed solution. Congress may decide that the price of policing foundations' businesses is not worth the benefit which accrues to society from the charitable activity made possible by business income. But it should at least weigh the values involved before limiting all business activities of foundations.

(2) The Treasury's second argument is that "foundations are able to lease business assets owned free of debt to operating subsidiaries, [and] siphon off most or all of the business profits by means of rent which is deductible by the subsidiary but not taxable to the parent foundation . . " TREASURY REPORT 31. But when subsidiaries pay unreasonable rents, the excess has not been allowed as a business expense of the company. E.g., Royal Farms Dairy Co., 40 T.C. 172, 187-91 (1968). Although the question has not been litigated, the excess paid the foundation in such situations should not be treated as rent, but rather as a disguised distribution of business profits taxable as unrelated business income. Or, it may be argued that the foundation is a partner or joint venturer with the business subsidiary, and therefore subject to the unrelated business income tax. See Woodward v. Campbell, 235 F.2d 268 (7th Cir. 1950) (exempt American Legion post joint venturer with bookie); Lanning, Tax Erosion and the "Bootstrap Sale" of a Business, 108 U. PA. L. REv. 623, 688 (1960). Since the evil which the Treasury identifies can be prevented under present law, unless the burden of enforcing the law is too heavy, the Treasury's solution is more drastic than the problem warrants.

(3) The Treasury's third criticism, that funds which should go to charity are denied because invested in losing businesses, seems invalid. The trustees of charities, should they make a mistake, will not long invest their money where it is not earning profits.

(4-5) The remaining criticisms are that operation of businesses results in self-dealing and that the officers lack time to administer funds for charity. These may be the Treasury's best arguments, but they are also its least well substantiated. Unless the evil alleged is substantial, it is hardly enough to justify the limitations proposed.

671950 Hearings 170. Exempt employee beneficiary associations, \& 501(c)(9), and benevolent life insurance associations, $\S 501(c)(12)$, are required to raise 85 per cent of their income from members. Other limitations apply to the income producing activities of teachers retirement funds, §501(c)(11), and cemetery companies, § 501(c)(13). 
be applied. ${ }^{68}$ The only decision on the question relied on Congress' policy of competitive equality and concluded that exemption must be removed. ${ }^{69}$ Again, although the competitive advantage to such organizations is doubtful, making the provisions applicable would prevent tax base shrinkage without loss of exemption.

In definining taxable income for purposes of the provisions, "business" should be given the same meaning as in other sections of the Revenue Code, ${ }^{70}$ such as those allowing deduction of business expenses. ${ }^{71}$ The meaning of "unrelated" requires analysis of the organization's need to engage in the business as part of its exempt activity. ${ }^{72}$ Thus, for example, a college radio station may be considered "related."73 The exclusion of so-called "passive" investment income-rents, royalties, dividends and capital gains-from unrelated business income ${ }^{74}$ has caused a definitional problem similar to one which arises elsewhere in the Code, and courts have properly used the precedents developed elsewhere to resolve it. For example, the Tax Court has applied the tests developed to distinguish "business" from "investment" for capital gains purposes to determine whether receipts from an exempt organization's sale of real estate were taxable as business income. ${ }^{75}$

It may be objected that the reasoning of this comment encourages exempt organizations to engage in business. But if taxed on the profits,

68 Suggesting no loss of exemption are: Note, Federal Income and New York Real Property Charitable Tax Exemptions: Application of the "Exclusive" Test, 35 ST. JoHN's L. REv. 96, 106 n.52 (1960); Moore \& Dohan, Sales, Churches, and Monkeyshines, 11 TaX L. Rev. 87, 111 (1956); Note, 50 VA. L. Rev. 1243, 1249 (1964). Such a result would be inconsistent with the policy of preventing competitive advantage, but would accord with a policy of special subsidy for certain organizations. Note, 48 MINN. L. Rev. 1149,1166 n.66 (1964), argues that the organizations not covered are to be allowed no substantial business activity.

69 People's Educ. Camp Soc'y, Inc. v. Commissioner, 331 F.2d 923 (2d Cir. 1964), affirming 39 T.C. 552 (1963), cert. denied, 379 U.S. 839 (1964).

70 The unrelated business income tax provisions were meant to adopt the meaning of business developed elsewhere in the Code. H.R. ReP. No. 2319, 81st Cong., 2d Sess. 109 (1950), 1950-2 Cum. Bull. 380, 409; S. Rep. No. 2375, 81st Cong., 2d Sess. 106 (1950), 1950-2 GUM. BULL. 483, 559.

71 INr. REv. CODE OF 1954, § 162.

72 It is not at all clear why a competitive "unrelated" business should be taxed and a similar "related" business not. Each in its own way furthers the exempt purpose and each has the same effects on competitors, whatever that may be. See notes 59-63 supra and accompanying text.

73 Treas. Reg. \& 1.513-1(a)(4) (1958), as amended, T.D. 6525, 1961-1 GuM. BuLL. 186. See Comment, Colleges, Charities, and the Revenue Act of 1950, 60 YALE L.J. 851, 85657 (1951); Note, 34 Notre Dame LAw. 238, 247-48 (1959).

74 INT. Rev. CoDE OF 1954, § 512(b)(1)-(5).

75 See The Marian Foundation, 19 CCH Tax Ct. Mem. 99 (1960). See also Cooper Tire \& Rubber Co., 36 T.C. 96 (1961), aff'd, 306 F.2d 20 (6th Cir. 1962); Robert A. Welch Foundation v. United States, 228 F. Supp. 881 (S.D. Tex. 1963). 
there is no apparent reason why they should not be allowed to do so. Even under the case law businesses may be operated if "incidental." Since "incidental" is a relative term and has been interpreted to require comparison with the exempt activities, businesses which earn substantial profits have sometimes been allowed if the profits were not more than an "incidental" amount of the organization's income. For example, an organization was allowed to engage in a business producing $\$ 20,000$ when its other income was $\$ 350,000,76$ but another's exemption was lost when its business produced $\$ 15,000$ while its other income was only $\$ 37,000.77$ Use of the unrelated business income tax would simplify the law by eliminating the "incidental" test and would deal in each case with the factor at which the courts have been covertly aiming-unfair competition by untaxed business.

76 Milwaukee Ass'n of Commerce v. United States, 72 F. Supp. 210 (E.D. Wis. 1947). 77 Evanston-North Shore Bd. of Realtors v. United States, 320 F.2d 375, 381 n.4 (Ct. Cl. 1968). 